\title{
Review
}

\section{Radio Benjamin}

\author{
Walter Benjamin, Lecia Rosenthal, (ed.) \\ Verso, New York, 2014, 424 pp., \$29.95, ISBN 10: 1781685754
}

Contemporary Political Theory (2016) 15, e54-e57. doi:10.1057/cpt.2015.52;

published online 6 October 2015

Radio Benjamin is an immensely helpful volume to introduce Walter Benjamin's many radio broadcasts to an English speaking audience. Although many of his radio plays have long been available in German and some are already available in English, Lecia Rosenthal has done a great job in comprehensively collecting translations of these radio broadcasts, along with a few related writings of Benjamin's on radio as a unique form of media. Sadly, there is no extant recording of Benjamin's own voice as he performs his radio shows. What a pleasure it would be to hear him giving life to his words (and how fitting it would be for this author, who famously resisted his own textual authority, to have his voice serve as a kind of material alternative to his words). Still, the transmissions as written show Benjamin in a wonderful light. While he himself was often disparaging of his radio broadcasts (as Rosenthal states, he often stated that he just did them to make a living), they represent a side of Benjamin that we don't generally see in his other writings.

For one thing, many of Benjamin's radio shows are intended for children. As a writer, Benjamin can be famously opaque (perhaps deliberately so) but in the radio broadcasts we see him in a more informal and jovial mode. Furthermore, as they are meant for a wider audience, there is less a concern in these pieces for philosophy and all of its complications and more a demonstration of how for Benjamin particular media have a unique effect on what is communicated and how that communication operates. Another way to say this is that in these plays, the author takes a bit more of a back seat; although there is, of course, craft involved in his radio shows, there is also a deference to the audience that is facilitated by the radio itself. In one of the essays on radio at the end of the volume, Benjamin argues that, unlike theater or other media of his day, radio is marked by the fact that listeners can readily switch it off or change channels. In radio, it is the listener who commands; it is his/her attentions that are primary.

Although Benjamin claims that with radio a 'barbarism' of 'dull, inarticulate masses' has 'reached its peak', he goes on to say that this trend 'appears ready to recede' (p. 364). Insofar as Benjamin is always more interested in the 'expertise of the listener [or reader or viewer]' over and above that of the author, for Benjamin the 
radio holds a special promise to combat the dulling of the mass audience present in so many media of his day. In his view, the radio comes into one's home 'where the voice is like a guest; upon arrival, it is usually assessed just as quickly and as sharply'. Because radio comes into our lives, it produces the 'audience on its side, as experts. And nothing is more important than that' (p. 364).

Benjamin further writes (in another essay in the volume) that radio is revolutionary because, whereas many forms of popular expression need to clothe their intentions by appealing to what they believe to be popular beliefs (hence promulgating those very beliefs in the name of pursuing them), radio allows a direct expression of popular interest (again because of the power of the listener). Thus, radio offers 'a case of popularity that not only mobilizes knowledge in the direction of the public, but mobilizes the public in the direction of knowledge. In a word: true popular interest is always active; it transforms the substance of knowledge and has an impact on the pursuit of knowledge itself' (p. 370).

In other words, the medium of radio helps to overcome the way that popular culture is a mere vehicle for ideology and phantasm; it offers the potential for the material and technical practices of radio to override that ideology and flip the relationship between audience and purveyor of knowledge to the advantage of the former and the detriment of the latter.

This is Benjamin at his best; whereas he bemoans, as so many of his generation did (and so many still do), the loss of high art and culture and the onslaught of popular culture, Benjamin did not submit to any easy snobbery and elitism. His solution to the crisis of culture is not to return to a purer 'before' but rather to go down into the very material of popular culture, the experience of engagement, and see that as its own kind of response and solution. If radio was intended as a tool by which to control and dominate the masses, its technical aspects thwart that aspiration; the vehicle for such domination becomes a means, however unexpectedly, to distribute agency to the very group who is intended to be dominated.

In this way there is a great deal of thought and also a pointed politics behind these apparently light and easy radio shows. Amidst the charming stories that he tells about floods and dialects, toys and brass works, there is a deeply subversive and radical streak afoot. Those familiar with Benjamin more generally will recognize a similar cast of characters: thieves, bootleggers, outlaws, magicians, hangers-on and drunkards. Such figures also haunt the margins of his philosophical writings. But given the ways that radio allows him to move out of the conventions of standard textual authority, in his radio programs, Benjamin's characters themselves take a delight in being able to both express and flout convention.

Benjamin's characters reflect the unique media that gives them form. Quite often the characters openly discuss or perform the way that radio is a purely auditory environment. In one of his radio plays, for example, the characters find themselves in a dense fog where they can't see and can only communicate orally. In another radio program, about the massive Brass Works near Eberswalde, he touts the benefits of 
this lack of visuality. He offers that even if the audience could see the works themselves, 'What would you see? Very simple: just about as much as I can describe here with words. That is: next to nothing' (p. 70). Benjamin goes on to describe how to see a machine from the outside tells you nothing compared to its internal (and hence, invisible) workings and so 'one can say that the closer one wants to get to what is going on in such an immense plant ... the further one has to distance oneself from it. And we should think of our few minutes here on the radio as if they were the gondola of a tethered balloon from which we can see into the whole operation' (p. 71). In this way (and in a way that is very characteristic of Benjamin more generally), he offers the limitations of an omniscient narrator even as he also indicates the power and reach of the media that formally merely conveys that narrator's beliefs and opinions.

Readers who are familiar with Benjamin's work will also see a lot of allusions to his more formal writings such as a reference to Grandville and the arcades of Paris in his radio program 'the Railway Disaster at the Firth of Tay' (p. 171). He also touches on some of the great German authors that interested him, albeit in his usual unorthodox fashion. In one of his funnier plays 'What the Germans were Reading While Their Classical Authors were Writing,' Benjamin impersonates 'the voice of the enlightenment,' among other characters and focuses not on the great words of the famous German authors (Goethe, Kleist et al.) but rather on their anxieties about the fate of books, education and the like. As he tells us in a separate essay that reflects on these writings 'the radio play in question strives for the closest possible contact with the research recently undertaken in so-called audience sociology. It would see its highest confirmation in being able to captivate the specialist no less than the layman, even if for different reasons. And with that, the concept of a new popularity appears to have found its simplest definition' (p. 171). Here, we see that, once again, the attempt to control and awe a larger population (as the reverence for classical German authors might suggest), becomes, in Benjamin's hands, a means by which the audience itself becomes the experts (experts on themselves, as it were) with a concomitant dispersal of awe and power.

I think that Rosenthal was wise to put the theoretical essays at the very end (and there isn't very much of them anyway) because to read them earlier might ruin the pleasure of the romps that Benjamin takes us through in his radio plays (especially the ones he wrote for children). Retroactively, we can see the craft in his writing but, left to his/her own devices, the reader gains a great deal from the sheer joy and lightheartedness of these plays.

One constant in almost all of these plays is a sense and description of magic. Magic - and the phantasmagoria itself that Benjamin describes as enveloping us - surely has its bad connotations; it is part of how we are captivated by capitalism. But magic cuts all ways, and it is also what exposes these phantasms as such; just as we can be aware of the fraud involved in a magic act and still enjoy the show, so too does Benjamin's bringing our attention to the illusions of our modern life not so much ruin them but 
allow us a different (and more subversive) relationship to them. This, I think, was the animating force behind his radio broadcasts, and in Radio Benjamin, these forces are on full, and wonderful, display.

James Martel

San Francisco State University, San Francisco, CA 94132, USA

E-mail: jmartel@sfsu.edu 